\title{
PERFORMANCE ANALYSIS OF 19 AMBON STATE MIDDLE SCHOOL USING BALANCE SCORECARD APPROACH
}

\author{
Rudolf Kempa* and Rosmaryn Tutupary \\ Faculty of Teacher Training and Educational Sciences \\ Pattimura University, Ambon - Maluku, Indonesia \\ *email : rudolfkempa@fkip.unpatti.ac.id
}

\begin{abstract}
Performance analysis using the balance scorecard approach enables the acquisition of a comprehensive picture of its performance including the ability of schools to meet the satisfaction of education stakeholders (stakeholders). The use of the Balance Scorecard approach in measuring school performance is seen from 4 perspectives, namely financial perspective where schools are expected to provide better education services to the community, customer perspective where schools are expected to empower the community in decision making processes and evaluation of school performance evaluations, internal process perspectives where schools expected to provide results in accordance with the programs and activities that have been planned, as well as learning and growth perspectives where the school is expected to improve and create value, but in this study only limited to 2 perspectives, namely the customer perspective and learning and growth perspective. This study aims to determine: The performance of Ambon 19th Junior High School from the customer aspect, the performance of Ambon 19th Junior High School from the aspects of learning and growth. This research was carried out in Ambon 19 Junior High School in five months. The method used is a survey method with quantitative descriptive research type. The population of this study were all 19Ambon Junior High School students, amounting to 911 students and 911 parents. Sampling of this study was carried out using proportional random sampling technique which was carried out randomly in 3 classes namely 90 people and 90 students' parents. Data is collected through a Likert scale questionnaire instrument, which will be tested to determine the validity and reliability of the instrument. Data from the results of this study were analyzed with the SPSS program to determine school performance as seen from Physical Forms (Tangibles), Reliability, Responsiveness, Assurance and Empathy. From the results of the analysis and discussion it can be concluded that: The level of customer satisfaction (students) on school performance both on the five dimensions of service quality, namely: tangibility, reliability, responsiveness, assurance, and empathy have a very high level of satisfaction explained by $99 \%$ level satisfaction with school performance; and the level of customer satisfaction towards learning and growth oriented to employee satisfaction, alumni tracking and information systems have a very high level of satisfaction that can reach $98 \%$ very satisfied so that school performance is stated to be very good with a score of 85 scores.
\end{abstract}

Keywords: School Performance, Balance Scorecard Approach

\section{Introduction}

Measuring school performance is an important issue in Whole School Development (PSS) / School Integrated Development (SID). In line with the increasing dynamics of community demands and demands for transparency, accountability, flexibility and better services, the measurement of school performance is a key component in planning, developing, implementing and managing / managing schools (Othman and Abd. Rauf, 2009).

The use of performance indicators can provide information about efficiency and effectiveness or the level of achievement of programs designed by schools in overcoming various problems encountered. Performance indicators are also very important to measure 
how well schools have carried out quality improvement (quality improvement) and what efforts and strategies must be done to improve quality continuously (CORE, 2013).

Correspondingly, Wohlstetter and Mohrman (Hasballah, 2010: 67) state that SchoolBased Management is a political approach to redesigning school organizations by giving authority and power to school participants at the local level to advance their schools. The intended local participants are the principal, teachers, supervisors, parents of students, surrounding communities, and students themselves. Ambon 19 Junior High School has a contribution in improving the quality of national education. As an educational institution 19 Junior High School Ambon is a public organization whose main focus is to meet the satisfaction of stakeholders, namely students, parents, education personnel, teachers, community and government. Performance measurement with a balance scorecard approach allows Ambon 19 Junior High School to obtain a comprehensive picture of its performance including the ability of schools to meet the satisfaction of education stakeholders (stakeholders).

The use of the Balance Scorecard approach in measuring school performance is seen from four perspectives, namely a financial perspective where the school is expected to provide better education services to the community, a customer perspective where the school is expected to empower the community in the decision making process and evaluation of school performance evaluation, internal process perspective where the school It is expected to provide results in accordance with the planned programs and activities, as well as learning and growth perspectives where the school is expected to increase and create value.

Based on the explanation above, the researcher conducted a study with the title: Analysis of the performance of Ambon 19 Junior High School using the balanced scorecard approach" which focuses on the problem (1) How is the performance of Ambon 19 Junior High School if measured from the customer aspect? And (2) What is the performance of Ambon 19 Public Middle School if measured from the learning and growth aspects? With the aim to find out: Ambon 19 Junior High School Performance from the aspect of customers and 19Ambon Junior High School Performance from the learning and growth aspects.

\section{Research Methods}

\section{Definition of Performance}

Etymologically, performance in English is called "performance", or work performance, work performance, work achievement, work results, performance, and work performance (E. Karwati and D. J. Priansa, 2016: 50). Based on the scope, performance can be understood in three perspectives, namely individual performance, group performance and organizational performance (E. Karwati and D. J. Priansa, 2016: 50).

Performance is the result obtained by an organization both profit oriented and non profit oriented organizations produced over a period of time (Irham Fahmi, 2015: 2) More explicitly Armstrong and Baron, (2004: 29) say performance is the result of work that has a relationship with strong organizational strategy goals, customer satisfaction and economic contribution. Furthermore Indra Bastian (2001: 329) states that performance is a picture of the level of achievement of the implementation of an activity / program / policy in realizing the goals, objectives, mission, and vision of the organization as outlined in the formulation of an organization's strategic planning.

In addition, performance is the actual work or output produced by a particular unit or entity. Meanwhile, assessment or measurement shows the ability and process used to measure and control certain activities and events. Yaghi and Neely (2008) define the concept of performance measurement as a process of measuring the efficiency and effectiveness of actions or activities. The concept of a performance measurement system 
can be interpreted as a collection of criteria / indicators (set of metrics) used to measure efficiency and effectiveness (Bourne et al, 2003).

Based on the opinions of the experts above, it can be concluded that performance is the work that can be achieved by a person, a group of people in an organization and an institution/organization in accordance with their respective authorities and responsibilities in order to achieve the desired organizational goals.

\section{Definition of Performance Measurement}

Measurement of organizational performance is a management tool used to improve the quality of decision making and accountability. In general, performance measurements provide quantitative information about key aspects of the activities carried out. This information is produced quantitatively through the use of tests, surveys, and data analysis or through qualitative means, such as; observation, interview and portfolio review. Theoretically, performance appraisal, whether quantitatively or qualitatively, focuses on changes that can be observed and measured in an organization.

Based on the description above it can be concluded that performance measurement is the measurement process carried out on various activities within an organization both individual, group and organization / institution.

\section{School Performance Measurement}

Measurement of organizational performance is a management tool used to improve the quality of decision making and accountability of Whittaker (Tangkilisan, 2007: 171). In line with that organizational performance measurement is the process of recording and measuring the achievement of the implementation of activities in the direction of achieving the mission through the results displayed in the form of a product, service or a process, Stout (Tangkilisan, 2007: 174).

According to Bastian (2001: 330) Measurement of organizational performance will encourage the achievement of organizational goals and will provide feedback for continuous improvement efforts. Therefore a performance measurement system must be built in such a way that information about performance can be obtained as much and as accurately as possible.

In connection with organizational performance including schools. According to Mardiasmo (2009) a system for measuring public sector performance is a system that aims to help public managers assess the achievement of a strategy through financial and non-financial measurement tools. The measurement of public sector performance is carried out to fulfill three purposes. First, to help improve government performance so that it can help the government focus on the goals and objectives of work unit programs. Second, public sector performance measures are used for resource allocation and decision making. Third, the measurement of public sector performance to realize public accountability and improve institutional communication.

Schools are organizations that have the main task of providing quality education services to the community. In relation to these education services, the government has established National Education Standards as a reference basis for measuring school performance. Therefore, by taking into account various experts' opinions about the dimensions of organizational performance measurement, the measurement of school performance in this study refers to the National Education Standards, as stated in PP No. 19 of 2005. There are eight National Education Standards that can be used as a reference for measuring school performance, as stated in Article 2 Paragraph (1), namely content standards, process standards, graduate competency standards, educator and education personnel standards, facilities and infrastructure standards, management standards, financing standards, and education assessment standards. 
Based on the description above it can be concluded that the measurement of school performance is an evaluation activity that is carried out routinely every year, to assess and evaluate the extent to which an educational institution has met the National Education Standards.

\section{Balanced Scorecard Approach}

Balance scorecard consists of two words namely balanced and scorecard according to Kaplan and Norton (1996: 7) Balanced shows that the performance of personnel or employees is measured in a balanced manner and viewed from two aspects namely financial and non-financial, short-term and long-term, and in terms of internal and external. While the Scorecard is a card used to record the score of a person's performance results which will be used to compare with the actual performance results.

The Balanced Scorecard approach is an instrument in strategic planning and management systems that is widely used in business, government, and nonprofit organizations. Mulyadi (2001: 1) states that the Balanced Scorecard consists of two words, namely the scorecard and balanced. Scorecards are used to plan and record employee performance scores. Next, the performance score will be compared with the score that has been planned or targeted for evaluation purposes. Balanced means that performance is measured in a balanced, financial and non-financial sense, short term and long term, as well as internal and external.

The Balanced Scorecard is a tool that has three elements namely a measurement system, a strategic management system, and a communication tool (Niven, 2003: 15). The Balanced Scorecard emphasizes financial and non-financial measures, short-term and long-term, internal and external running in balance (Mulyadi, 2007: 3). The purpose of using the Balanced Scorecard is to direct business activities to the vision and strategy of the organization, develop internal and external communication, and monitor the performance of the organization for its intended purpose.

While Anthony, Banker, Kaplan, and Young, 1970 (Sedarmayanti, 2014: 169) stated that the Balanced Scorecard is a measurement and management system that shows the performance of a business unit from four perspectives: finance, customers, internal business processes and growth. In line with that Anthony, Banker and Young, 1997: 27. (Sedermayanti, 2014: 169). Stating that the Balanced Scorecard is a management system and measure that looks at the performance of a business unit from four perspectives: financial, customer, internal business processes and learning and growth.

According to Brandon, and Ralph, 1997 (Sedarmayanti, 2014: 169) states that the Balance Scorecard is a system approach to organizing performance measures into an integrated and easily understood framework based on four different perspectives that set corporate goals. From the above definition it is concluded that the Balanced Scorecard is a system of approaches to measure performance carried out by companies through a measurement framework based on four perspectives: financial, customer, internal business processes and learning and growth processes.

The balanced scorecard fits perfectly with the current type of organization where the focus is placed on strategy and vision, not control. The four perspectives in the balanced scorecard include financial and non-financial benchmarks, which in their application are placed in an integrated and balanced framework to evaluate and improve school performance comprehensively. These four perspectives are explained in table 1 . 
Table 1. Four Perspectives in the Balanced Scorecard

\begin{tabular}{|c|c|c|}
\hline Perspective & Target & Indicator \\
\hline Finance & Value for money & $\begin{array}{l}\text { - Increasing the effectiveness and efficiency of } \\
\text { school spending } \\
\text { - Developing effective, efficient, transparent } \\
\text { and accountable school financial management }\end{array}$ \\
\hline Customer & $\begin{array}{l}\text { Customer } \\
\text { Satisfaction }\end{array}$ & \begin{tabular}{|l} 
- \\
$\begin{array}{l}\text { Improving the quality of service to customers } \\
\text { (students) }\end{array}$
\end{tabular} \\
\hline $\begin{array}{l}\text { Internal Business } \\
\text { Processes }\end{array}$ & 8 SNP through EDS & $\begin{array}{ll}- & \text { Developing services to meet the needs of } \\
\text { student learning. } \\
\text { - }\end{array}$ \\
\hline Learning \& Growth & $\begin{array}{l}\text { - Employee Ability } \\
\text { - Information } \\
\text { Systems } \\
\text { - Organizational } \\
\text { Climate }\end{array}$ & $\begin{array}{ll} & \text { Level of employee satisfaction } \\
\text { - } & \text { Faster completion time } \\
\text { - } & \text { The creation of a conducive and pleasant } \\
\text { work climate }\end{array}$ \\
\hline
\end{tabular}

To measure customer satisfaction can be measured in two ways, namely to what extent students feel satisfied with school services so that they distribute their feelings of satisfaction to other parties so that demand is increasing and by measuring the value of school services.

The school's internal business perspective is to build organizational excellence through continuous improvement of the school's internal processes. In the perspective of an internal business that is the focus of the school is what school should excel in? How do schools build these advantages? (Mahmudi, 2010: 144). In accordance with the BSC concept there are three things that schools must run, namely the innovation process, the operation process, and the postsale process. Innovation in the context of schools is an effort to present a superior curriculum that is in line with the needs of the business world and the industrial world.

The operational process aspect is a process in which schools deliver their products to students in a good learning process. The indicators are a) effective use of time; b) a quality learning process by innovating using multi-source, multi-method and multi-media, c) increasing the quality of teacher education (equivalent to S1), d) increasing school facilities / infrastructure (libraries, laboratories, computers) and e) increasing the value of Criteria Minimum completeness (KKM) every year. These matters are regulated in the National Education Standards related to school business processes, Process Standards, Educator and Education Workforce Standards, Standards, Graduates Competency Standards, Infrastructure Standards, Management Standards, and Education Assessment Standards. The postsale process aspect (after sales service) is an opportunity for recruitment, facilities for alumni and the creation of an alumni network.

Learning and growth perspective according to Kaplan and Norton (1993: 134) emphasizes "Can continue to improve and create value?". This perspective emphasizes efforts to maintain and build organizational excellence in the long run. The existence of human resources is a major component, because important principles in the perspective of learning and growth are the ability of teachers and employees, the ability of information systems, and the level of motivation / empowerment. Teacher and employee satisfaction is very important, this is because if teachers and employees have high satisfaction with school management will have a positive impact on improving school performance. To 
find out the level of teacher and employee satisfaction, schools should conduct regular surveys of teacher and employee satisfaction.

\section{Research Method}

This research is a quantitative descriptive study. This research is seen from the objective of a descriptive study that is research that seeks to describe school performance as measured by the balanced scorecard approach. This research was conducted at Ambon 19 Junior High School in Nusaniwe sub-district. The data that the author requires in this research process is available at SMP Negeri 19 Ambon. Sampling in this study uses simple random sampling technique (simple random sampling technique) and saturated sampling technique. The sampling technique for each balanced scorecard perspective, for the customer perspective sample (Students and Parents of Students) 90 students and 90 parents, while for the learning and growth perspective sample based on data on the number of educators and educators at SMP Negeri 19 Ambon in 2019 from there are 37 annual school reports consisting of PNS teachers, Non PNS teachers and Education Personnel. The data used in this study are primary data and secondary data. Primary Data is data obtained from the first source, both individuals or individuals. For questionnaire data collection, the questionnaire is a closed question in which the respondents' statement was limited by the choice of answers. The instrument used to obtain data on customer performance variables and internal business process performance variables in this study was a closed questionnaire. The questionnaire uses a Likert scale, where each item consists of five (5) alternative answers Strongly Agree (SS), Agree (S), Hesitate (R), Disagree (TS) and Strongly Disagree (STS).

While the instrument used to obtain data on performance variables and perspective performance of learning and growth is a school document. The validity test in this study used the Product Moment method or the Pearson method (Riduwan 2010: 98), with a result of 0.89 and a reliability test using the Cronbach alpha method with a result of 0.90

\section{Data Analysis Techniques.}

Data analysis technique in this research is quantitative descriptive which is used in describing aspects related to research variables which include aspects of customers and learning / growth. In addition, an analysis of quantitative data was obtained through questionnaires. Weighting each performance based on the perspective of the balanced scorecard. Weighting technique is a technique used to assign weight values to a number of indicators or attributes. According to Beckwith (1973) and Zeleny (1982) in Rita (2011), groups of people tend to spread their perceptions to the attributes they consider important.

Respondents' answers to the questionnaire were quantified to find the average value of performance on a growth and learning perspective using a Likert scale. From the processing of these data will be known the level of employee satisfaction. To measure the level of satisfaction is done by comparing the maximum score with the perception score of educators and exceptionalness of the existing reality.

$$
\text { Satisfaction level }=\frac{\text { acquisition score }}{\text { maximum score }} X 100 \%
$$

The use of a Likert scale with interval data 1-5 to indicate the level of satisfaction of respondents under study is the teaching staff and education of Ambon 19 Junior High School. Measuring customer performance as well as growth and learning performance consists of two indicators, namely employee satisfaction and the school information 
system. Each indicator has the lowest and highest score of 1-5, then the lowest total score is 2 (two) and the highest score is 10 (ten). Thus for the aspects of performance growth and gradation learning performance can be measured as shown in table 2. follows:

Table 2. Scale of Growth and Learning Perspective Measurement

\begin{tabular}{|c|c|c|}
\hline Value (percentage) & Scale & Category \\
\hline $84,01 \%-100 \%$ & 5 & Very satisfied \\
\hline $68,01 \%-84 \%$ & 4 & Satisfied \\
\hline $52,01 \%-68 \%$ & 3 & Quite satisfied \\
\hline $36,01 \%-52 \%$ & 2 & Not satisfied \\
\hline $20,00 \%-36 \%$ & 1 & Very dissatisfied \\
\hline
\end{tabular}

Source: Sugiyono, 2010 reprocessed.

Internal Customer Satisfaction Level Against School Services to measure the level of customer satisfaction done by using a Minnesota satisfaction questionnaire consisting of 20 questions.

Table 3. Categories and Weight of Respondents' Responses to Employee Satisfaction Level

\begin{tabular}{|l|c|}
\hline \multicolumn{1}{|c|}{ The answer } & Weight / Score \\
\hline Very satisfied / very good & 5 \\
\hline Satisfied / good & 4 \\
\hline Neutral / good enough & 3 \\
\hline Not satisfied / not good & 2 \\
\hline Very dissatisfied / not very & 1 \\
\hline
\end{tabular}

Source: Sugiyono, 2009: 93.

Respondents' answers to the questionnaire were quantified to find the average value of performance on a growth and learning perspective using a Likert scale. From the processing of these data will be known the level of employee satisfaction. Measuring customer performance as well as growth and learning performance consists of two indicators, namely employee satisfaction and the school information system. Each indicator has the lowest and highest score of 1-5, then the lowest total score is 2 (two) and the highest score is 10 (ten). Thus for aspects of growth performance and gradation learning performance can be measured as shown in the following table:

Table 4. Scale of Growth and Learning Perspective Measurement

\begin{tabular}{|c|c|c|}
\hline Value (percentage) & Scale & Category \\
\hline $84,01 \%-100 \%$ & 5 & Very satisfied \\
\hline $68,01 \%-84 \%$ & 4 & Satisfied \\
\hline $52,01 \%-68 \%$ & 3 & Quite satisfied \\
\hline $36,01 \%-52 \%$ & 2 & Not satisfied \\
\hline $20,00 \%-36 \%$ & 1 & Very dissatisfied \\
\hline
\end{tabular}

Source: Sugiyono, 2010 reprocessed. 


\section{Results and Discussion}

\section{Customer Perspective}

Customer perspective is a perspective developed in using the balance scorer approach. In the context of the school organization the main customers are students during the learning process at school. The measurement of customer perspective performance is done by measuring the level of service quality and the level of customer satisfaction by using the theory of service quality from Zeithaml, et al (1990) in Herma (2011). Customer (student) perception of the services provided by Ambon 19 Junior High School is known from the questionnaire / questionnaire distributed to 90 students. The questions in the questionnaire represent five dimensions of service quality, namely: tangibility, reliability, responsiveness, assurance, and empathy. The recapitulation of the results of the discussion of the five dimensions in customer aspects is as follows:

Table 5. Value of Customer Performance in SMP Negeri 19 Ambon

\begin{tabular}{|c|l|c|c|c|c|c|c|}
\hline \multirow{2}{*}{ No } & \multirow{2}{*}{ Indicator } & \multicolumn{3}{|c|}{ Average score } & \multirow{2}{*}{$\begin{array}{c}\text { TKP } \\
\mathbf{\%}\end{array}$} & \multirow{2}{*}{ Weight } & \multirow{2}{*}{ Category } \\
\cline { 3 - 7 } & & Reality & Expectations & Gap & & \\
\hline 1 & Tangibility & & 4,3 & $-0,6$ & 98,5 & 5 & Very satisfied \\
\hline 2 & Reliability & 4 & 4,2 & $-1,3$ & 96.9 & 5 & Very satisfied \\
\hline 3 & Resonsiveness & 4 & 4,3 & $-0,3$ & 99,3 & 5 & Very satisfied \\
\hline 4 & Assurance & 4 & 4,5 & $-0,2$ & 99,7 & 5 & Very satisfied \\
\hline 5 & Emphaty & 4 & 4,5 & $-0,09$ & 99,8 & 5 & Very satisfied \\
\hline & Rata-Rata & 4 & 4,36 & $-0,5$ & 99,3 & 5 & Very satisfied \\
\hline
\end{tabular}

(Source: Primary data processed in 2019)

The tangibility / physical appearance dimension is manifested in the service of Ambon 19 Junior High School through building facilities, courtyards, facilities, libraries and comfortable learning spaces. This study explains the level of customer satisfaction on tangibility aspects based on customer responses (students) to the statements in the questionnaire that the school yard is neat, clean classrooms, clean bathrooms and toilet, safe school environment, sports facilities, worship facilities, health facilities, learning resources / library books and school personnel dressed neatly.

From the table above it can be explained that the average score of the reality level is 3.9 , the expectation level is 4.3 , the average gap is -0.6 with a satisfaction level of $98.5 \%$ which indicates the very satisfied category. Thus that there are some physical parts that must receive attention, namely the school yard, learning resources, books / libraries, health facilities, all of these components are important factors in supporting the learning process so that students can learn well which ultimately can improve the quality of education.

The reliability dimension is manifested in the service of Ambon 19 Junior High School through school personnel present on time, serving quickly, serving with a smile, serving without demanding rewards and serving as needed. From the table above it can be explained that the average score of reality level is 4.1 , the expectation level is 4.2 , the average gap is -1.3 with a satisfaction level of $96.9 \%$ which shows the very satisfied category. Thus, there are several components of the level of trust that must receive attention, namely school personnel serving with a smile, school personnel serving quickly, school personnel arrive on time, all of these components can be implemented well but have not been able to meet customer satisfaction levels. For the Reliability dimension, although there are components that have gaps, overall the satisfaction level of 96.9\% shows that the customer is very satisfied. This is an important factor in supporting 
the learning process so that students can learn well which ultimately can improve the quality of education.

The dimension of responsiveness / responsiveness is realized in the service of Ambon 19 Junior High School through school personnel responding to needs quickly, being able to explain intentions, being fair in service and serving openly in providing services. From the table above it can be explained that the average score of the reality level is 4,3 the level of expectation is 4.3 , the average gap is -0.3 with a satisfaction rate of $99.3 \%$ which shows the very satisfied category. Thus that there are some components that have gaps namely school personnel are able to explain their intentions, school personnel serve quickly, school personnel respond to your needs quickly, and school personnel respond quickly to customer needs, these components do not meet customer or customer expectations services provided by school personnel to customers have not been good but have a satisfaction level of $99.3 \%$ indicating that personnel respond can explain intentions, serving customer needs quickly is an important factor in supporting all school programs so students can meet their learning needs properly which ultimately can improve the quality of education.

The assurance / guarantee dimension can be realized in the service of Ambon 19 Junior High School through school personnel providing accurate information, providing a safe atmosphere in the school, using a persuasive approach in solving problems at school, communicative, always in the same direction in conveying information and being competent. From the above table it can be explained that the average score of reality level is 4.3 expectation level 4.5 , the average gap is -0.2 with a satisfaction level of $99.7 \%$ which shows the very satisfied category. Thus that there are some components that have gaps namely communicative school personnel, school personnel provide a safe atmosphere in this school shows that only one component that has not provided a high level of satisfaction but other components have provided services that can guarantee / provide guarantees for all things in a school institution is legitimate or accountable is an important factor in supporting the learning process so that students can learn well which ultimately can improve the quality of education.

The empathy dimension / shows seriousness is manifested in the service of Ambon 19 Junior High School through school personnel understanding learning difficulties and willing to help students, serious in carrying out tasks, helping to solve problems / difficulties faced by students, serious in listening to complaints, having commitment to the quality of education and empathy for students. From the recapitulation table above it can be explained that the average score of reality level is 4.4 expectation level 4.5 , the average gap is -0.09 with a satisfaction level of $99.8 \%$ which shows the very satisfied category. Thus it can be said that the customer response to empathy / shows the seriousness of Ambon 19 Public Middle School in general can be said to be good at $99.8 \%$. The empathy component / shows seriousness still has a gap that is only in serious school personnel in carrying out their duties meaning the other four components have fulfilled customer expectations or the services performed by school personnel to customers in this component are good so that this dimension has a level of satisfaction of $99.8 \%$ indicating that the service can guarantee / provide guarantees for all things in school institutions intended for the benefit of students which is an important factor in supporting the learning process so that students can learn well which ultimately can improve the quality of education.

\section{Analysis of Learning and Growth Perspective Performance in SMP Negeri 19 Ambon}

Learning and growth aspects are steps to identify the determinants of the quality of education. The size of school excellence depends on what criteria we use and what 
activities we do in line with the progress and changes that occur and that we experience in accordance with creativity, innovation in learning. Measurement of learning and growth perspective uses 4 criteria, namely the level of student satisfaction with teacher performance and services provided, the level of employee and teacher satisfaction and tracking of alumni and information systems.

Table 6. Recapitulation of Learning and Growth Perspective Performance Measurement Scores

\begin{tabular}{|c|l|c|c|l|}
\hline NO & Aspect & Precentage & Score & Category \\
\hline 1 & Student Satisfaction Level on Teacher & $99,41 \%$ & 5 & Very satisfied \\
\hline 2 & Level of Student Satisfaction with & $96,3 \%$ & 5 & Very satisfied \\
\hline 3 & Level of employee satisfaction with work & $98,19 \%$ & 5 & Very satisfied \\
\hline 4 & Level of Satisfaction with Information & $98,1 \%$ & 5 & Very satisfied \\
\hline & Average & $98 \%$ & 52 & Very satisfied \\
\hline
\end{tabular}

(Source: Primary data processed in 2019)

The level of student satisfaction with teacher performance is an assessment of what students experience inside and outside the classroom. Measurement of the level of student satisfaction with teacher performance can be explained that the level of student satisfaction on teacher personality competencies, pedagogical competencies, professional competencies and social competencies that have a student satisfaction level of $99.41 \%$ of teacher performance, the level of student satisfaction with services provided at school is $96.3 \%$, the level of employee satisfaction with work was $98.19 \%$ (very satisfied), alumni traceability and information systems were one of the important factors in educational institutions, amounting to $98.1 \%$ (very satisfied). From these results it can be concluded that the level of customer satisfaction with the learning and growth perspective can be said to be very high or very satisfied (98\%)

\section{Discussion of Research Results}

From the analysis of research data and will be discussed about the performance of Ambon 19 Junior High School using a balance scorer approach that is limited to two aspects, namely the perspective of the level of customer satisfaction with the performance of Ambon 19 Junior High School and the customer's perspective on learning and growth.

\section{a. Perspective level of customer satisfaction}

The level of customer satisfaction perspective in this case is students regarding 5 dimensions, namely the Physical / Tangible Appearance dimension, the reliability dimension, the responsiveness dimension, the assurance dimension, and the empathy dimension. These five dimensions according to students' responses or perceptions are at a high level of satisfaction or very satisfied where the school has provided adequate physical appearance or infrastructure for student learning, school personnel have performed their duties well in serving students and in creating a conducive environment for students learning, besides that in providing service the students are very satisfied both providing learning facilities, administrative services, giving attention and motivation as well as the use of learning strategies, learning media and the provision of varied learning resources in improving the quality of education.

\section{b. Customer Perspectives on Learning and Growth}

Learning and growth are the main targets in implementing school programs by all school personnel. It can be said that in the provision of information, services and learning 
processes it can be said to be very satisfied both regarding the implementation of teacher competence, alumni tracking and provision of information systems for SMP Negeri 19 Ambon. well fulfilled so that all customers are very satisfied with what is in the school institution. Everything that has been prepared is very influential on the admission of new students and the reception of alumni in the higher schools above.

\section{Conclusions}

a. The level of customer satisfaction (students) on school performance both on five dimensions of service quality, namely: tangibility, reliability, responsiveness, assurance, and empathy have a very high level of satisfaction that is explained by 99\% level of satisfaction with school performance.

b. The level of customer satisfaction with learning and growth oriented to employee satisfaction, alumni tracking and information systems have a very high level of satisfaction that can reach $98 \%$ very satisfied so that school performance is stated to be very good with a score of 85 scores.

\section{References}

Asmendri.2012. Management of Quality Improvement of School / Madrasah Education. Stone cage: STAIN Batu cage Press

Ary, D .; Jacobs, L.C., \& Razavieh, 1985. Introduction to Research in Educational (3rded.). New York: Holt, Rinehart and Winstin.

Balian, E.S. 1982. How to Design, Analyze, \& Write Doctoral Research, Englewood Cliffs, New Jersey: Prentice-Hall, Inc.

Creemers, B.P.M. \& Reynolds, D. (ed). 1993. School Effectiveness and School Improvement, An International Journal of Research, Policy and Practice. 3rd New York: Random House.

Dalen, V., \& Deobold, B. 1973.Understanding Educational Research, New York: MaGraw-Hill Company.

Danim, S. 2003. New Vision of School Management (From the Bureaucracy Unit to the Academic Institution). Jakarta: Earth Literacy.

Kerlinger, F.N. 1973. Fundation of Behavioral Research, New York: Holt. Rinehard and Winston.

Nasir, M. 1988. Research Methods, Jakarta: Ghalia Indonesia.

Owens, R.G. 1991. Organizational Behavior In Education. Philadelphia: Prentice Hall International, Inc.

Rahabav, Patrisius. 2014. Headmaster of Schools in the Autonomous Era of Education, Yogyakarta, Kanisius.

Robbins, S.P. 2002. Management: Concepts and Practices. Englewood Cliffs, New Jersey: Prentice Hall, Inc.

Sonhadji, A., K.H. 1991. Lecturer in Institutional Development, Papers, Presented in Short Course for Higher Education Academic Staff in Semarang.

Sugiyono, 2013. The 5th Printing Education Research Method, Bandung: CV Alfabeta.

Wahab, 2008. Policy Analysis: From Formulation to Implementation of State Policy Second Edition. Earth Literacy. Jakarta. 